\title{
The Kveim test in leprosy
}

\author{
R. J. W. REES \\ Laboratory for Leprosy and Mycobacterial Research, \\ National Institute for Medical Research, London, N.W.7
}

\begin{abstract}
Summary
From the older literature it has been claimed that a significant proportion of patients with the tuberculoid, but not the lepromatous, form of the disease, gave positive Kveim reactions. It is concluded, however, from a review of this older literature that none of the claims are based on studies using a validated Kveim antigen and that the majority of the readings were based on macroscopic, rather than microscopic assessment.
\end{abstract}

The International Study by Siltzbach on Kveim tests in leprosy patients using a validated antigen and assessed microscopically reveal no positive reactions among fifty-seven patients with all types of leprosy from Finland, Israel, Italy and Turkey. However, this same study on Japanese patients gave two positive and five equivocal Kveim reactions among ten lepromatous patients and one equivocal reaction among three tuberculoid patients. Our own studies in Malaysia with the same validated Kveim antigen used by Siltzbach and assessed microscopically gave one weak positive Kveim reaction among twenty-one lepromatous patients and four equivocal Kveim reactions among nine tuberculoid patients.

It is concluded from these results that, with the possible exception of Chinese and Japanese patients, false positive Kveim reactions are extremely rare in patients with all types of leprosy. Therefore in parts of the world where leprosy is endemic the Kveim reaction can still be accepted as an important confirmatory diagnostic test for sarcoidosis.

It is suggested that further surveys of Kveim reactivity be undertaken on Chinese and Japanese leprosy patients, since both have a similar ethnic origin, in order to determine whether such patients are more liable to elicit a granulomatous reaction to Kveim antigen.

\section{Introduction}

In this symposium Dr J. R. Mikhail has presented data and reviewed the literature on which is based the efficacy of a microscopically positive intracutaneous Kveim reaction for the diagnosis of sarcoidosis. Using a validated Kveim test material some
$80 \%$ of patients with sarcoidosis give a positive reaction. Moreover, the specificity of the Kveim reaction has been fully substantiated by the International Kveim Trial on a world-wide basis by Siltzbach (1967) who showed that there was an insignificant number of false positive reactions, including less than $1 \%$ of such reactions in patients with tuberculosis-another disease associated with epithelioid granulomatous formation. However, in this symposium we have been presented by $\mathrm{Dr} D$. N. Mitchell with an entirely different and new situation in Crohn's disease where his recent results show a high proportion of Kveim-positive reactions in patients with this disease.

It is therefore pertinent and even more relevant to consider the results of Kveim tests in human leprosy which is both a mycobacterial infection and a disease associated with epithelioid granulomatous formation. However, the results of the Kveim test in human leprosy have been variable. Negative (macroscopic) findings were reported in ten patients, in the philippines with lepromatous leprosy (Wade, 1951), and in a group of twenty in Mexico that included tuberculoid as well as lepromatous forms (Goldman; see Wade, 1951). On the other hand, the test was considered positive in four of fifteen Bantu patients with tuberculoid leprosy, but not in eight with lepromatous disease; the average diameter of the nodules in the former group substantially exceeded that in the latter (Kooij, 1964).

The evidence on Kveim reactions in leprosy is thus unclear; it is based mainly on macroscopic lesions and a validated Kveim antigen was not used in any of the studies. Therefore, from the old literature if a Kveim reaction was present at all in leprosy, the prevalence would seem to be much lower than in sarcoidosis.

\section{The International Kveim Test Study (1960-66)}

In this study undertaken by Siltzbach (1967) around the world using a Chase-Siltzbach type 1 suspension of Kveim antigen of known potency (Chase, 1961; Siltzbach, 1961) patients with leprosy were included from Finland, Israel, Italy, Japan and 
TABLE 1. Kveim tests in leprosy from the International Study by Siltzbach*

\begin{tabular}{|c|c|c|c|c|c|}
\hline & \multirow[b]{2}{*}{ Country } & \multirow[b]{2}{*}{ Total } & \multicolumn{3}{|c|}{ Type of leprosy } \\
\hline & & & Lepromatous & Tuberculoid & Indeterminate \\
\hline \multirow[t]{5}{*}{ Negative results } & Finland & 5 & 2 & 3 & - \\
\hline & Israel & 11 & 5 & 5 & 1 \\
\hline & Italy & 3 & 3 & - & - \\
\hline & Turkey & 38 & 18 & 5 & 15 \\
\hline & & 57 & 28 & 13 & 16 \\
\hline \multirow[t]{2}{*}{ Positive results } & Japan & 13 & $10(2 \mathrm{P} ; 5 \mathrm{E})$ & $3(1 \mathrm{E})$ & - \\
\hline & & 70 & 38 & 16 & 16 \\
\hline
\end{tabular}

Turkey. Including their more recent data from Turkey (Celikoglu \& Siltzbach, 1969) a total of seventy patients with different forms of leprosy were tested with validated Kveim antigen. The results from these trials are abstracted in Table 1. From all the countries except Japan there were fifty-seven patients, twenty-eight with lepromatous, thirteen with tuberculoid and sixteen with indeterminate types of leprosy and all these failed to produce histologically a Kveim reaction. However, the thirteen patients from Japan gave two false positive Kveim reactions, both weakly positive, and five equivocal reactions in the ten patients with lepromatous leprosy and one equivocal reaction in the three patients with tuberculoid leprosy. Thereafter, with the exception of Japan there was no evidence that a validated Kveim antigen gave reactions in patients with leprosy. However, two, albeit weak, Kveim reactions and six equivocal reactions among thirteen Japanese patients with leprosy was even, on small numbers, in excess of the incidence of such reactivity to Kveim antigen by any other groups of patients in the International Kveim Test Study.

\section{Study in Malaysia}

This study was carried out in conjunction with Dr Siltzbach at the Medical Research Council's Leprosy Research Unit in Malaysia (Pearson et al., 1969). It included thirty-nine leprosy patients, predominantly from the same ethnic group (Chinese) and area (Malaysia) using one source of validated Chase-Siltzbach Type 1 Kveim antigen (Lots 8 and 10) and assessing the reaction histologically. The patients fell into three groups: twenty-one with lepromatous leprosy; nine with tuberculoid leprosy; and a third group of nine patients (eight lepromatous, one tuberculoid) who showed poor 'conversion' to tuberculin sensitivity after BCG vaccination. All the patients had received anti-leprosy treatment, varying from 1 month to 26 years, and in most cases for 2 or more years; only seven could be considered to have active disease. Two patients had been treated also for pulmonary tuberculosis, which had responded and was inactive at the time of the Kveim tests. All the patients had been tuberculin tested in the past, most on several occasions, and the test was repeated just before the Kveim test if it had not been done within the previous few months. The three groups by race and age of patients are given in Table 2 .

TABLE 2. Race and age of patients in the three groups tested with Kveim

\begin{tabular}{|c|c|c|c|c|}
\hline \multirow[b]{2}{*}{ Group } & \multirow[b]{2}{*}{ Race } & \multicolumn{2}{|c|}{ Age (years) } & \multirow[b]{2}{*}{ Total } \\
\hline & & Under 30 & Over 30 & \\
\hline \multirow{4}{*}{$\begin{array}{l}\text { Lepromatous } \\
\text { leprosy }\end{array}$} & Chinese & 14 & 3 & 17 \\
\hline & Malay & 3 & 0 & 3 \\
\hline & Aborigine & 0 & 1 & 1 \\
\hline & Total & $17^{*}$ & 4 & 21 \\
\hline $\begin{array}{l}\text { Tuberculoid } \\
\text { leprosy }\end{array}$ & Chinese & $6^{*}$ & 3 & 9 \\
\hline \multirow{4}{*}{$\begin{array}{l}\text { Poor responders } \\
\text { to tuberculin after } \\
\text { BCG (eight lepro- } \\
\text { matous, one tuber- } \\
\text { culoid leprosy) }\end{array}$} & Chinese & 5 & 1 & 6 \\
\hline & Malay & 1 & 0 & 1 \\
\hline & Aborigine & 2 & 0 & 2 \\
\hline & Total & $8^{* *}$ & 1 & 9 \\
\hline
\end{tabular}

\section{Objectives}

In lepromatous leprosy there is a reduced sensitivity to tuberculin (Badger et al., 1940; Leiker, 1961 and Wayson, 1934), and also impaired ability 
TABLE 3. Macroscopic and microscopic results of Kveim tests

\begin{tabular}{|c|c|c|c|c|c|c|c|}
\hline Group & $\begin{array}{c}\text { Tuberculin Test } \\
\text { category }\end{array}$ & $\begin{array}{c}\text { Total } \\
\text { biopsied }\end{array}$ & $\begin{array}{l}\text { Mean maximum } \\
\text { diameter of } \\
\text { nodule }(\mathrm{mm})\end{array}$ & $\begin{array}{l}\text { Mean diameter } \\
\text { of nodule at } \\
\text { biopsy (mm) }\end{array}$ & $\begin{array}{l}\text { Kveim } \\
\text { positive }\end{array}$ & $\begin{array}{l}\text { Kveim } \\
\text { equivocal }\end{array}$ & $\underset{\text { negative }}{\text { Kveim }}$ \\
\hline \multirow{4}{*}{$\begin{array}{l}\text { Lepromatous } \\
\text { leprosy }\end{array}$} & Negative & 7 & 0.9 & 0.9 & 1 (weak) & 1 & 5 \\
\hline & Positive & 9 & $1 \cdot 3$ & 0.8 & 0 & 1 & 8 \\
\hline & Reverted & 5 & $1 \cdot 2$ & 0.8 & 0 & 0 & 5 \\
\hline & Total & 21 & $1 \cdot 1$ & $0 \cdot 8$ & 1 & 2 & 18 \\
\hline \multirow{3}{*}{$\begin{array}{l}\text { Tuberculoid } \\
\text { leprosy }\end{array}$} & Negative & 2 & $2 \cdot 5$ & 0 & 0 & 1 & 1 \\
\hline & Positive & 7 & $2 \cdot 4$ & $1 \cdot 7$ & 0 & 3 & 4 \\
\hline & Total & 9 & $2 \cdot 4$ & $1 \cdot 3$ & 0 & 4 & 5 \\
\hline $\begin{array}{l}\text { Poor responders to } \\
\text { tuberculin after BCG } \\
\text { (eight lepromatous } \\
\text { and one tuberculoid } \\
\text { leprosy) }\end{array}$ & Negative & 9 & $2 \cdot 2$ & $1 \cdot 3$ & 0 & 2 & 7 \\
\hline
\end{tabular}

to develop delayed hypersensitivity to 2,4-dinitrochlorobenzene (Turk \& Waters, 1969; Waldorf et al., 1966). This, together with the constant finding of a negative lepromin test in lepromatous leprosy, suggests that in this disease, as in sarcoidosis, there might be an association between anergy and Kveim reactivity. Particular attention was therefore paid to Kveim reactivity in relation to tuberculin sensitivity in the lepromatous group.

A high prevalence of Kveim positivity was reported in a small group of apparently healthy young adults in Britain who had failed to be 'converted' to tuberculin sensitivity after two BCG vaccinations (Hart, Mitchell \& Sutherland, 1964). With these findings in mind, we decided to carry out Kveim tests in leprosy patients who were 'nonconverters' to tuberculin sensitivity after BCG vaccination.

The patients were selected from a group of about 850 who had been tuberculin tested during a hospital survey (Table 2). All had been tested with 1 TU (Lot RT23 with Tween, WHO) followed, in those giving negative results, by 20 TU. Patients whose tests with the larger dose of tuberculin were also negative, i.e. less than $5 \mathrm{~mm}$ induration, were vaccinated with BCG (Glaxo freeze-dried vaccine). The vaccination sites were inspected after 2 weeks to check for a papule with or without ulceration, and again at 12 weeks for the presence or absence of a scar. At this time the patients were re-tested using $20 \mathrm{TU}$, and those with readings to the larger dose of tuberculin of less than $10 \mathrm{~mm}$ induration were considered to be non-converters and eligible for the Kveim tests. Only nine of the original entry qualified; one of them had tuberculoid, but the other eight lepromatous, leprosy.

\section{Results}

A summary of the findings is given in Table 3 . It will be seen that one weak Kveim positive (histological) result and two equivocals were obtained in the twenty-one lepromatous cases, and four equivocals in the nine tuberculoid cases. The granulomata in the BCG group were equivocal in two of the eleven cases. All the remaining tests were negative. One patient in the lepromatous group with an equivocal Kveim test was not X-rayed. The chest radiographs of all other patients with positive or equivocal results were normal.

There was no clear association of granulomata with any particular tuberculin test result, but the numbers in the sub-groups were too small to be definite; nor was there any apparent association with the activity of the disease, the single Kveim positive and five of the seven equivocal results being in patients who had received more than 2 years of treatment.

The mean maximum diameter of the tuberculoid group nodules was $2.4 \mathrm{~mm}$ (range $0-5 \mathrm{~mm}$ ), whereas that of the lepromatous group was $1 \cdot 1 \mathrm{~mm}$ (range 0 to $5 \mathrm{~mm}$ ). It will be seen that only two out of the total of thirty-nine cases of leprosy had nodules of $5 \mathrm{~mm}$ or more diameter and both these were Kveim-negative.

In the present investigation care was taken to distinguish histological changes of leprosy from those typical of, or approaching, Kveim-positive appearances. In the tuberculoid group no acid-fast bacilli and no leprosy changes were seen in the Kveim biopsies. In the lepromatous group acid-fast bacilli and leprosy changes were absent too in the three patients who were either Kveim-positive (one patient) or equivocal (two patients); in the remaining eighteen 
there were small foamy cell infiltrations in twelve and acid-fast bacilli in eight; five were negative. There were granulomata present in the single positive and equivocal Kveim test-sites in the lepromatous and tuberculoid groups of patients. However, the proportion of epithelioid cells and the follicular arrangement of these and other cells within the granulomata were variable, and only in one case were these features sufficiently characteristic to be regarded as Kveim-positive.

In the BCG group two gave equivocal histological results and none of the macroscopic readings exceeded $4 \mathrm{~mm}$. Thus there was no evidence that in this special group BCG increased Kveimreactivity in patients with lepromatous leprosy.

\section{Discussion}

An advantage of the present study is that the Kveim material was a product which had been validated by use in the International Kveim Test Study (Siltzbach, 1964). It may be noted in this connection that a hospital patient suffering from lepromatous leprosy who developed sarcoidosis (diagnosed clinically and confirmed by lymph node biopsy) gave a strong positive Kveim test (macroand microscopical) with the same Kveim material.

Of the leprosy groups included here, the lepromatous group, aside from the one weak positive, had a proportion of equivocal Kveim test results little, if at all, higher than might be found in a normal population. On the other hand, the figure of four equivocal results among the nine tuberculoid cases is higher than one might expect; this correlates with the larger mean diameter of their nodules, though only one (Kveim negative) was $5 \mathrm{~mm}$ or more. In the BCG group the two equivocal granulomatous responses to the Kveim suspension were no more typical in appearance than those in the other groups, and it is likely that in lepromatous leprosy, as in sarcoidosis (Israel \& Sones, 1966), BCG fails to augment Kveim reactivity. Certainly the BCG group did not show the high prevalence of Kveim positivity found in apparently healthy persons who had been BCG vaccinated but failed to be converted to tuberculin sensitivity (Hart et al., 1964).

It remains uncertain why some patients with leprosy, particularly the tuberculoid group, develop granulomata which are not typical of a positive Kveim test result. One hypothesis is that these subjects have skin changes which predispose to granulomata following the injection of certain materials; such granulomata would represent an isopathic type of reaction (Sagher et al., 1953), though this was reported in lepromatous leprosy.

Bearing in mind that the frequency of Kveimpositive results decreases as the duration of sarcoi- dosis lengthens, a limitation of the present study is that all the patients had been treated for leprosy, many of them for a long period. It would not be ethical to delay treatment until a Kveim test had been completed, but it would be reasonable to test immediately on admission, while the disease is undoubtedly in an active state. A further study on these lines is planned.

It is of particular interest that from our own studies in Malaysia and those of Siltzbach's International Studies, the great majority of positive and equivocally positive reactions to Kveim antigen in leprosy come from Chinese or Japanese patients, since both have a similar ethnic origin. A causal connection here must await more extensive data on Chinese and Japanese patients.

However, our own studies together with those of Siltzbach based on the use of a fully validated Kveim antigen clearly show that, with the possible exception of Chinese and Japanese patients, false positive Kveim reactions are extremely rare in patients with all types of leprosy. Even in Chinese or Japanese patients with leprosy the incidence of false positive Kveim reaction is very small compared with the incidence of Kveim-positive reactions in patients with sarcoidosis. Therefore in parts of the world where leprosy is endemic the Kveim test should still be accepted as an important confirmatory diagnostic test for distinguishing leprosy from sarcoidosis, bearing in mind the additional importance of hilar adenopathy and pulmonary mottling on radiography as specific features of sarcoidosis.

\section{References}

Badger, L.F., Patrick, D.W., Fite, G.L. \& Wolfe, D. (1940) Leprosy: two strains of acid-fast bacilli isolated from a case of human leprosy. A comparison with other strains of acid fast organisms with particular reference to Lleras bacillus. National Institute of Health Bulletin, 173, 1.

Celikoglu, S. \& Siltzbach, L.E. (1969) A study of sarcoidosis and leprosy in Turkey employing the Kveim reaction. Diseases of the Chest, 55, 400.

Chase, M.W. (1961) The preparation and standardization of Kveim testing antigen. American Review of Respiratory Diseases, 84, suppl. p. 86.

Goldman, L. Quoted by Wade (1951).

Hart, P. D'ArCy, Mitchell, D.N. \& Sutherland, I. (1964) Associations between Kveim test results, previous BCG vaccination, and tuberculin sensitivity in healthy young adults. British Medical Journal, 1, 795.

IsRael, H.L. \& Sones, M. (1966) A study of Bacillus CalmetteGuérin vaccination and the Kveim reaction. Annals of Internal Medicine, 64, 87.

Kool, R. (1964) The nature of the Kveim reaction. Third International Conference on Sarcoidosis, Stockholm, 1963. Acta medica Scandinavica, 176, Suppl. 425, 79.

LEIKER, D.L. (1961) Studies on the lepromin test. IV. Influence of leprosy on the reactions to lepromin, tuberculin and the ' 875 bacillus' suspension. International Journal of Leprosy, 29, 496. 
Pearson, J.M.H., Pettit, J.H.S., Siltzbach, L.E., Ridley, D.S., Hart, P'Arcy \& ReEs, R.J.W. (1969) The Kveim test in lepromatous and tuberculoid leprosy. International Journal of Leprosy, 37. (In press.)

Sagher, F., Liban, E., Zuckerman, A. \& Kocsard, E. (1953) Specific tissue alteration in leprous skin. V. Preliminary note on specific reactions following the inoculation of living microorganisms ('Isopathic phenomenon'). International Journal of Leprosy, 21, 459.

Siltzbach, L.E. (1961) Current status of the NickersonKveim reaction. American Review of Respiratory Diseases, 84, suppl. p. 89.

Siltzbach, L.E. (1964) Significance and specificity of the Kveim reaction. Third International Conference on Sar- coidosis, Stockholm, 1963. Acta medica Scandinavica, 176, suppl. 425 , p. 74.

Siltzbach, L.E. (1967) An International Kveim Test Study 1960-66. Fourth International Conference on Sarcoidosis, Paris, 1966, p. 201. Masson et Cie (Paris).

TURK, J.L. \& Waters, M.F.R. (1969) Cell-mediated immunity in patients with leprosy. Lancet, ii, 243.

WADE, H.W. (1951) Leprosy and sarcoid. The Kveim test in leprosy patients and contacts. Journal of Investigative Dermatology, 17, 337.

Waldorf, D.S., Sheagren, J.N., Trautman, J.R. \& Black, J.B. (1966) Impaired delayed hypersensitivity in patients with lepromatous leprosy. Lancet, ii, 773.

WAYSON, N.E. (1934) Leprosy with tuberculosis in Hawaii. Public Health Reports (Washington), 49, 1201. 